\title{
The Development of a Natural Plankton Population in an Outdoor Tank with Nutrient-Poor Sea Water. II. Changes in Dissolved Carbohydrates and Amino Acids*
}

\author{
U. H. Brockmann ${ }^{1}$, K. Eberlein ${ }^{1}$, H. D. Junge ${ }^{2}$, E. Maier-Reimer ${ }^{3}$, D. Siebers ${ }^{4}$ \\ ${ }^{1}$ Institut für Organische Chemie und Biochemie der Universität Hamburg, Martin-Luther-King-Platz 6, D-2000 Hamburg 13, \\ Federal Republik of Germany \\ ${ }^{2}$ Bundesforschungsanstalt für gartenbauliche Pflanzenzüchtung, Bornkampsweg, D-2070 Ahrensburg, Federal Republic of \\ Germany \\ ${ }^{3}$ Max-Planck-Institut fuir Meteorologie, BundesstraBe 55, D-2000 Hamburg 13, Federal Republic of Germany \\ ${ }^{4}$ Biologische Anstalt Helgoland, Palmaille 5, D-2000 Hamburg 50, Federal Republic of Germany
}

\begin{abstract}
Interrelations between plankton communities and dissolved carbohydrates and amino acids were investigated under near-natural conditions in sea water enclosed in plastic tanks. In summer 1972 the development of a natural plankton population was followed in a $3-\mathrm{m}^{3}$ plastic tank for $28 \mathrm{~d}$. In the course of this experiment, concentrations of dissolved neutral carbohydrates and free amino acids were determined. Results are in the range of published data for the open sea with respect to concentrations (0.2--2.5 $\mu$ moles $\mathrm{dm}^{-3}$ total sugar; $0.2-3.1 \mu$ moles $\mathrm{dm}^{-3}$ total amino acids) and qualitative composition. A plankton succession was observed during the experiment; this was accompanied by distinct alterations in the concentrations of dissolved amino acids and carbohydrates. Glucose and lysine occurred in highest concentrations. Maximum rate of increase was 29 nmoles $\mathrm{dm}^{-3} \mathrm{~h}^{-1}$ for glucose, and 25 nmoles $\mathrm{dm}^{-3} \mathrm{~h}^{-1}$ for lysine. The rates of decrease are in the same range as bacterial uptake rates determined by various authors employing tracer methods. Numerous positive, highly significant correlations suggest heteropolysaccharides as one source of individual carbohydrates. Relations between certain species within the plankton succession and occurrence of dissolved organic substances were observed. Significant positive correlations existed between glucose and diatorns as well as between glucose, galactose, mannose, arabinose and ribose and phytoplankton biomass. There were also several significant positive correlations of amino acids, especially of valine, leucine and isoleucine with other biological parameters.
\end{abstract}

\section{INTRODUCTION}

The largest proportion of dissolved organic substances in sea water is presumed to be chemically resistant and of high molecular weight. Only a small fraction consists of chemically unstable substances, released by living organisms and subject to rapid biological and chemical transformation (Fogg, 1975; Bada and Lee, 1977). The latter group, which includes most of the amino acids and carbohydrates, may play an essential role in marine ecosystems in spite of low concentrations. These substances have a stabilizing effect, particularly in regeneration phases by extending the supply of nutrients (Wangersky, 1977). The processes

- This work was supported by the Sonderforschungsbereich 94, Hamburg, of the Deutsche Forschungsgemeinschaft. of production and utilization of dissolved organic matter are significant in a broad range of ecological interrelationships. Only a small percentage of dissolved organic matter (DOM) in the sea has been identified (Wangersky, 1972, 1978; Williams, 1975); its origin from plankton excretion or release is still a matter of discussion.

Phytoplankton is probably the most important source of DOM (Anderson and Zeutschel, 1970; Thomas, 1971; Haug and Myklestad, 1976; Duce and Duursma, 1977; Fogg, 1977; Myklestad, 1977; Sharp, 1977; Whittle, 1977). The release is dependent on the physiological state of the plankton cell. Carbohydrates are one of the main components of DOM released by phytoplankton, along with amino acids and fatty acids (Degens, 1970; Handa, 1970). It has been observed that, particularly when nitrate has become exhausted, 
the proportion of carbohydrates (and thus the $\mathrm{C} / \mathrm{N}$ ratio) increases (McAllister et al., 1961; Antia et al., 1963; Myklestad, 1974; Brockmann et al., 1977b) mostly in form of fixed reserve carbohydrates (McAllister et al., 1961; Antia et al., 1963, Myklestad, 1974; Brockmann et al., 1977b). In the stationary phase, an increased amount of carbohydrates is often released (Myklestad, 1977; Brockmann et al., 1974a, unpublished); this varies in composition with the species concerned (Myklestad, 1974, 1977). The composition of extracellular monosaccharides is also species specific (Allan et al., 1972; Haug and Myklestad, 1976). Amino acids dissolved in sea water are released by phytoplankton (Hellebust, 1965; Gocke, 1970; see also Hellebust, 1974; Whittle, 1977), but very little is known about excretion or loss under natural conditions.

An intracellular amino acid pool has been observed in connection with uptake (North and Stephens, 1969; Liu and Hellebust, 1974; Smith and Wiebe, 1976). Thus, a direct release process would appear conceivable. Zooplankters also have a pool of free amino acids at their disposal (Cowey and Corner, 1963; Jeffries, 1969). Release of amino acids from zooplankters is therefore also a possibility to be considered (Cowey and Corner, 1963; Johannes and Webb, 1965, 1970; Webb and Johannes, 1967, 1969; Butler et al., 1970; see also Corner and Davies, 1971; Conover, 1978). During grazing, amino acids and proteins probably also go into solution along with carbohydrates (Corner and Davies, 1971; Wheeler et al., 1974, 1977; Antia et al., 1975; Williams, 1975; Sepers, 1977).

The fact that so few investigations have been carried out on the relationship between DOM and plankton development (Morris and Foster, 1971; Storch and Saunders, 1978) can be explained by the difficulties arising from hydrodynamic influences leading to inhomogeneous plankton and substrate distributions in the field, thus complicating the analysis of biochemical interactions. In addition, laboratory results cannot be directly applied to the open sea. This is particularly the case for DOM release rates and factors influencing these rates (Nalewajko, 1966; Smith et al., 1977).

in water bodies separated from horizontal water exchange by physiologically inert plastic bags (Brockmann et al., 1974b), concentration changes of DOM and plankton development may be observed under near-natural conditions. In 1972, from July 8 until August 4 , we investigated a natural plankton population contained in $3 \mathrm{~m}^{3}$ sea water collected 1 nautical mile south of Helgoland (Southern North Sea). The unfiltered population within the untreated, relatively nutrient-poor sea water was kept in a flexible plastic tank of $4 \mathrm{~m}$ depth in the outer harbour of Helgoland. Within a few days, there were alternations of anabolic and catabolic phases in the regeneration system. This led to a succession of phytoplankters with 3 biomass maxima (diatoms, dinoflagellates and again diatoms) (Brockmann et al., 1977a) as well as a succession of zooplankters (ciliates and different small copepods with up to 3 cohorts (Brockmann et al., in preparation). Concentration changes of dissolved neutral carbohydrates and free amino acids were observed which paralleled the development of the natural phytoplankton population. The objectives of our research included assessment of the degree to which the composition and concentration of DOM in the tank corresponded to that in the open sea, as well as of time scales for qualitative and quantitative DOM changes compared with the plankton development in the tank.

\section{METHODS}

Experimental procedures. and statistical evaluation methods for the tank experiment in 1972 have been described previously (Brockmann et al., 1974b; Brockmann et al., 1977a). Samples of $250 \mathrm{ml}$ were collected at $0.2,1.0,1.8$ and $2.6 \mathrm{~m}$ depth in the tank and were then combined.

\section{Analysis of Dissolved Neutral Carbohydrates}

Immediately after collection, $1 \mathrm{~d} m^{3}$ samples were fixed by addition of $3 \mathrm{~cm}^{3}$ of $3.5 \%$ (wt/vol) $\mathrm{HgCl}_{2}$ solution. After $2 \mathrm{~h}$ at most they were filtered through $0.45-\mu \mathrm{m}$ membrane filters (cellulose nitrate; Sartorius) and stored at $4{ }^{\circ} \mathrm{C}$. Desalination was performed by means of electrodialysis with ion exchange membranes as described by Josefsson (1970), using Nepton membranes (Serva, C 61 AZL 183 and A 111 BZL 183). A constant electrical current of $1 \mathrm{~A}$ was maintained by a regulated D. C. power supply (PE 1213, Philips), adjusted to a maximum potential of $250 \mathrm{~V}$. After reaching the crossover point, this instrument operated in constant voltage service. In order to achieve complete desalination, tap water for cooling and degassing was led into the electrode compartments of the desalinator under constant pressure. After $36 \mathrm{~h}$ the desalted samples were removed and evaporated to $1 \mathrm{~cm}^{3}$. Then $1 \mathrm{~cm}^{3}$ of $2 \mathrm{~N}$ HCL was added and the mixture heated in a screw-capped tube fitted with a Teflon liner (Sovirel, Levallois's-Perret, France) for $2 \mathrm{~h}$ at $100^{\circ} \mathrm{C}$. The hydrolysates were neutralized with Dowex $1\left(\mathrm{HCO}_{3}{ }^{-}\right)(\mathrm{Nie}-$ dermeier, 1971) and purified by hexane extraction. The monosaccharides were extracted from the aqueous phase after reducing the volume with $85 \%$ ethanol. After vacuum desiccation over $\mathrm{P}_{2} \mathrm{O}_{5}$ they were converted to trimethylsilyl ethers (Vance and Sweeley, 1967). The derivates were evaporated to dryness and then 
redissolved in n-hexane. Finally, a defined amount of trimethylsilyl-mannitol was added as internal standard (Clamp et al., 1967; Vance and Sweeley, 1967; Bhakti et al., 1970). For gas chromatography of the carbohydrate derivates at different temperature programs see Siebers et al. (1972).

For method intercalibration some samples were additionally analysed with a carbohydrate analyzer (borate buffer) ZA 5100 (Biotronik, Munich).

\section{Analysis of Dissolved Amino Acids}

Samples of $1 \mathrm{dm}^{3}$ were fixed with $10 \mathrm{ml}$ chloroform. Within $2 \mathrm{~h}$ they were filtered through $0.45 \mu \mathrm{m}$ membrane filters (cellulose nitrate, Sartorius) and stored at $4{ }^{\circ} \mathrm{C}$. Before desalination the samples were adjusted to a pH of 2.0 with $\mathrm{HCl}$ and purified by threefold extraction with ethyl acetate. After the remaining ester had been removed by rotation evaporation, the aqueous phases were desalinated by ion exchange (Siegel and Degens, 1966; Palmork, 1969; Andrews and Williams, 1971). After adjustment of the $\mathrm{pH}$ to 9.5 with $\mathrm{NaOH}$ the samples were desalinated on a Chelex 100 column ( $\mathrm{Cu}^{2+}$-form, 200-400 mesh, Biorad), followed by elution of the sea water and rinsing with aqua bi-dest. Thereafter the amino acids were eluted from the column with $3 \mathrm{~N} \mathrm{NH}_{3}$. Copper ions were removed with Chelex $100\left(\mathrm{NH}_{4}{ }^{+}\right.$-form). The elutes were evaporated and analysed on a Unichrom-amino acid analyzer (Beckman).

\section{RESULTS}

\section{Neutral Carbohydrates}

The total concentration of dissolved neutral monosaccharides in the tank reached values of about $2.5 \mu$ moles $\mathrm{dm}^{-3}$. For comparison, the data for carbohydrates, phytoplankton and zooplankton are combined in Figure 1. All three components are of the same order of magnitude, between 20 and $200 \mu \mathrm{g} \mathrm{C} \mathrm{dm}^{-3}$. The carbohydrate carbon temporarily reached values several times higher than those of the phyto- or zooplankton. The concentration of particulate carbon during the entire experiment remained between 0.5 and $1 \mathrm{mg}$ $\mathrm{dm}^{-3}$ (Brockmann et al., 1977a). Glucose, galactose, mannose, fucose, rhamnose, xylose, arabinose and ribose were detected, along with some unidentified substances (Fig. 2). Glucose was the major component of the analysed carbohydrates with up to $74 \mathrm{~mol} \%$. It always accounted for at least $50 \%$ of the carbohydrate fraction. The concentration of the unidentified components $\mathrm{x}_{2}, \mathrm{x}_{3}, \mathrm{x}_{4}$, probably hexoses, was related to mannitol as internal standard. The retention times of these compo-

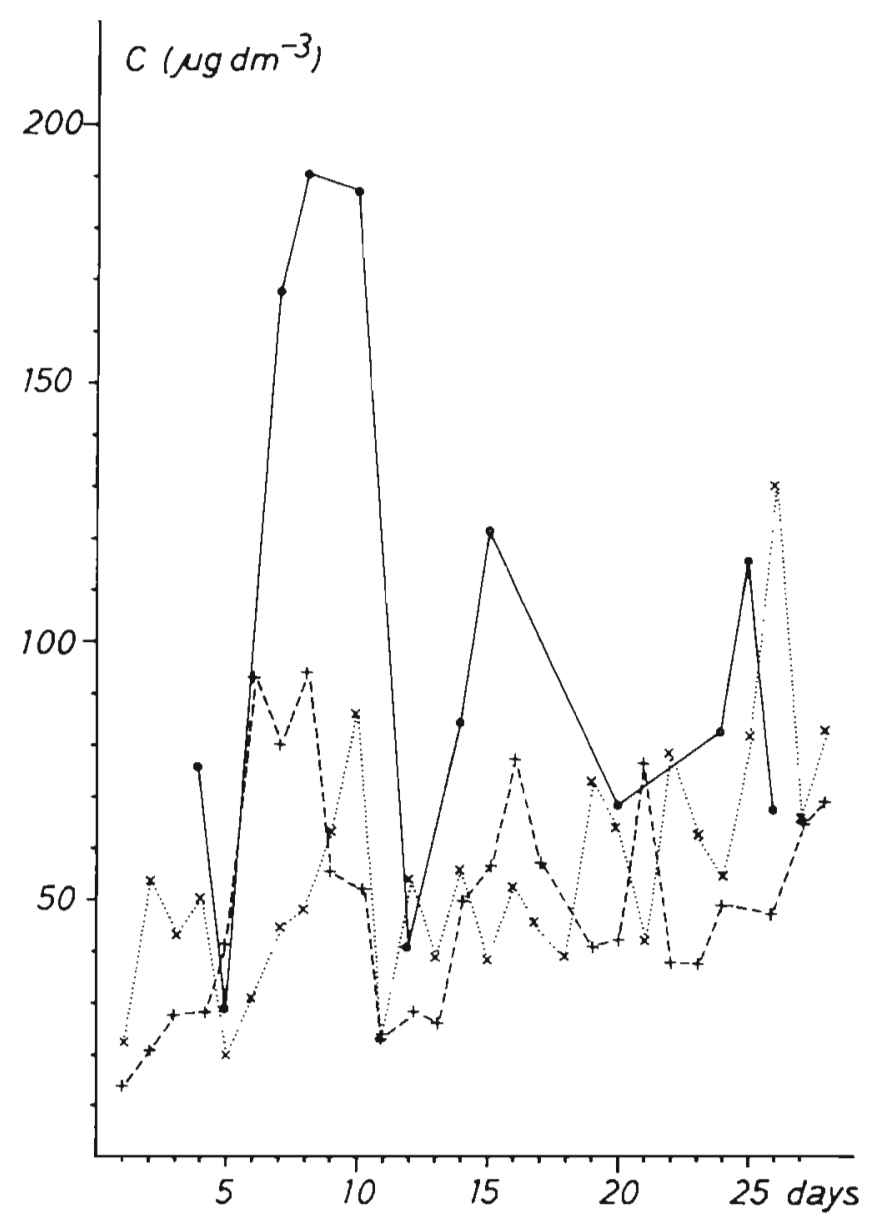

Fig. 1. Concentrations of dissolved carbohydrates (-), phytoplankton (---) and zooplankton (...) in $\mu \mathrm{g} \mathrm{C} \mathrm{dm}{ }^{-3}$ in a $3 \mathrm{~m}^{3}$ large foil tank from July 8 until August 4, 1972

nents, relative to $\alpha$-glucose, were $0.58,0.61$ and 0.77 , respectively.

Many of the sugars exhibited distinct maxima at various times between the 7 th and 10 th day. The maximum for glucose extended over a longer period including the maxima of all other sugars. The maximum rates of increase and decrease of glucose were $0.7 \mu$ moles $\mathrm{dm}^{-3} \mathrm{~d}^{-1}$. Relative maxima also occurred later in the experiment, around the 15th and 25th day.

The individual carbohydrates have numerous significant, positive rank correlations with each other (Fig. 3). Particularly mannose, xylose and rhamnose are related to each other, by highly significant correlations. Fucose is only correlated significantly with mannose and rhamnose.

A few significant correlations with several phytoplankton groups were found. For the entire period of investigation significant (95\% confidence interval) positive correlations existed between glucose and the diatoms as well as between glucose, galactose, mannose, arabinose and ribose and the phytoplankton 


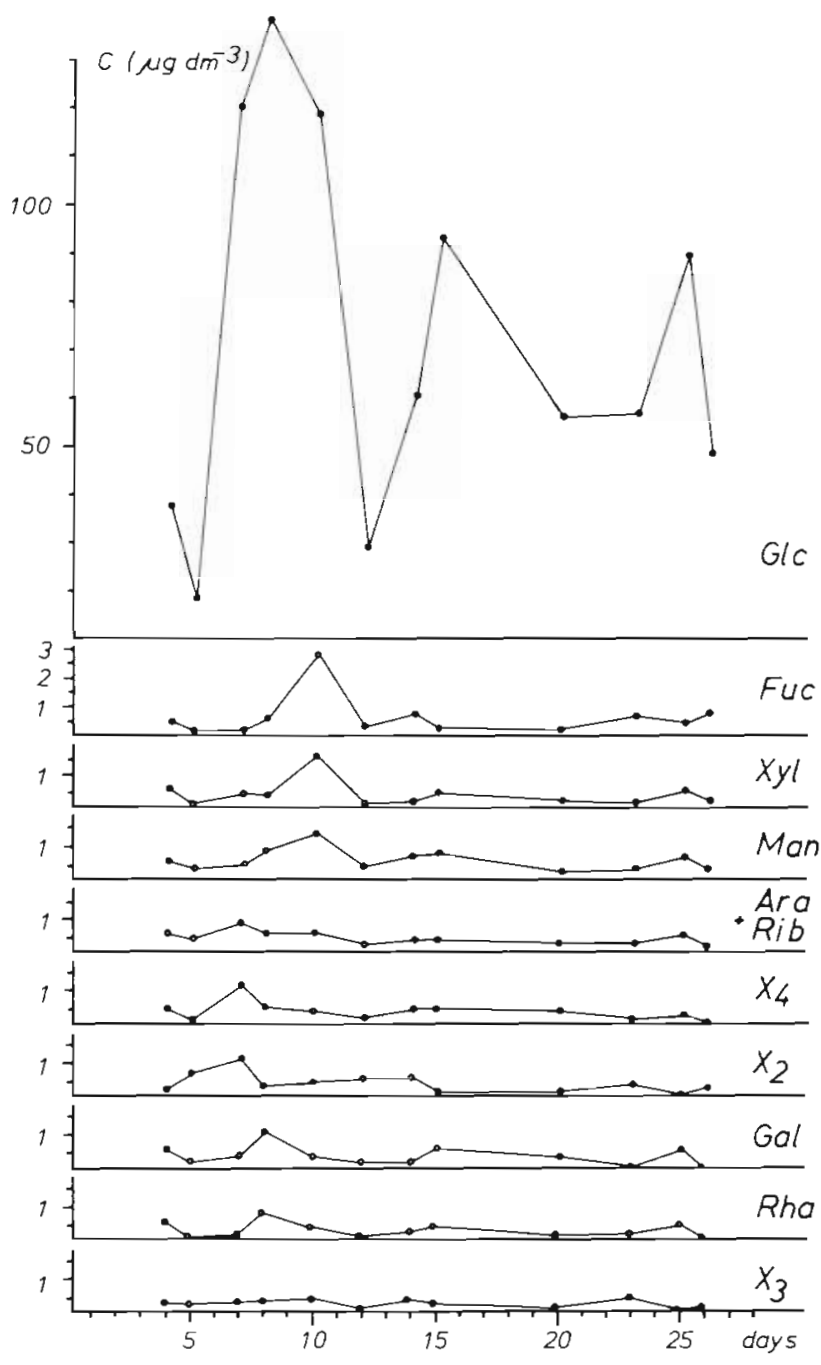

Fig. 2. Concentrations of individual carbohydrates after hydrolysis. ara: arabinose, fuc: fucose, gal: galactose, glc: glucose, man: mannose, rha: rhamnose, rib: ribose, xyl: xylose $\mathrm{x}_{2}, \mathrm{x}_{3}$ and $\mathrm{x}_{4}$ : unknown components (see text)

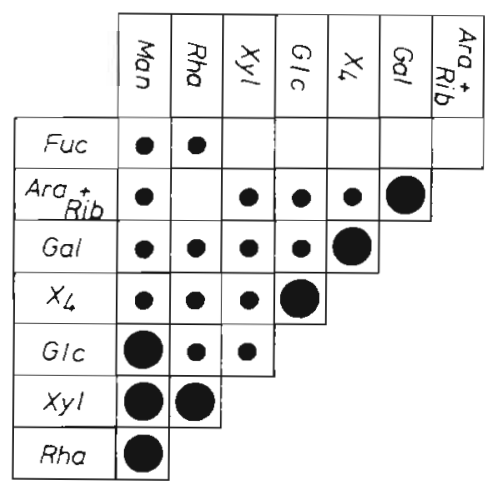

Fig. 3. Rank-correlations of individual carbohydrates. There are only positive significant correlations (filled circles.) Small points: statistical probability of 95,0 to $99,0 \%$; large points: 99,0 to $99,9 \%$. ( $x_{4}$ see legend to Fig. 2 and text) biomass. The sum of the phyto- and zooplankton biomass was also significantly correlated with glucose, as well as with other carbohydrates.

\section{Free Amino Acids}

In the course of the experiment the dissolved free amino acids reached a total concentration of $0.2-3.1$ $\mu$ moles $\mathrm{dm}^{-3}$. This value corresponds to about $200 \mu \mathrm{g} \mathrm{C}$ $\mathrm{dm}^{-3}$, comparable to the value for dissolved carbohydrates and thus in the same range as the phyto- and zooplankton carbon.

In terms of nitrogen, the dissolved amino acids, with $5 \mu \mathrm{g}$ at $\mathrm{N} \mathrm{dm}{ }^{-3}$, reached the same concentrations as nitrogen and ammonia, and half about the maximum $\mathrm{N}$-concentration of the particulate matter (Fig. 4).

The predominating amino acids were lysine and glycine (Fig. 5), followed by glutamic acid, serine and alanine. In addition to the amino acids shown in Figure 5, phenylalanine, proline and arginine were found in traces.

The concentration development of individual amino acids was subject to relatively large fluctuations in the

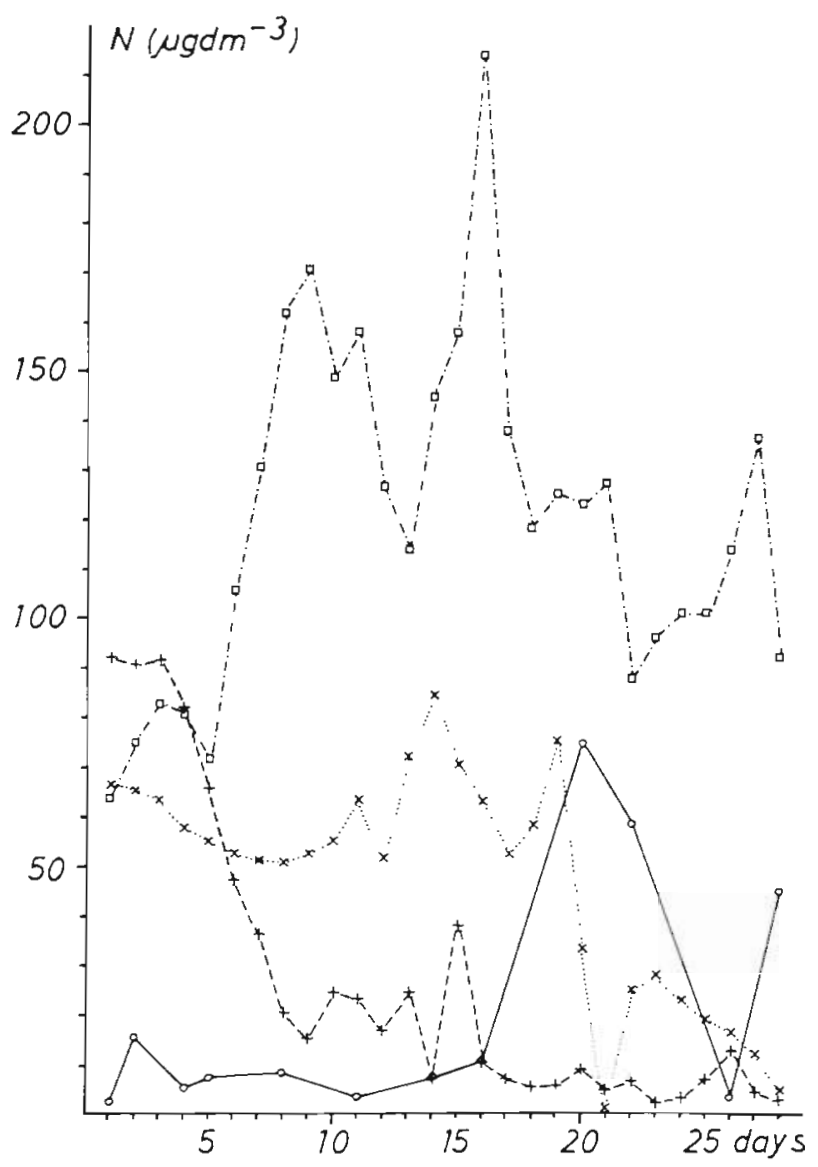

Fig. 4. Dissolved free amino acids (-), ammonia (--), nitrate (...) and particulate nitrogen (-. - ) in $\mu \mathrm{g} \mathrm{N} \mathrm{dm}^{-3}$ 


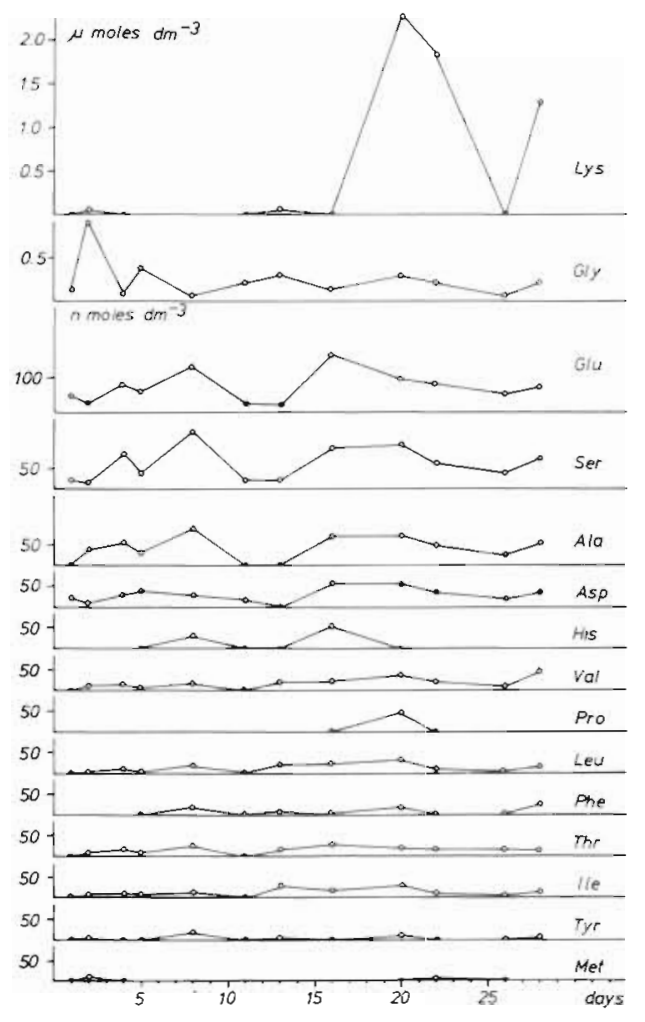

Fig. 5. Individual dissolved free amino acids. ala: alanine, asp: aspartic acid, glu: glutamic acid, gly: glycine, his: histidine, ile: iso-leucine, leu: leucine, lys: lysine, met: methionine, phe: phenylalanine, pro: proline, ser: serine, thr: threonine, tyr: tyтosine, val: valine

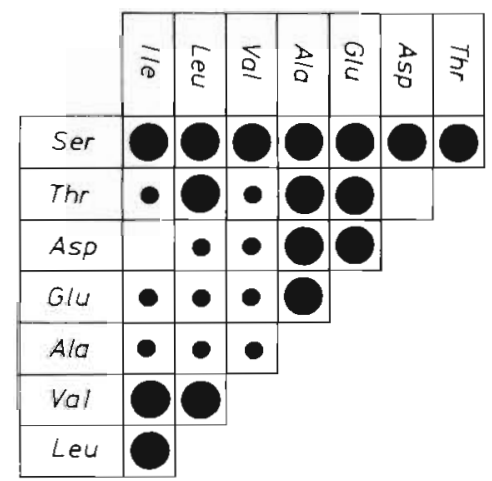

Fig. 6. Rank-correlations of individual free dissolved amino acids. Only positive significant correlations (see legend to Fig. 3)

12 samples analysed. This was especially the case for lysine, with maximum increase and decrease rates of 0.6 and $0.5 \mu$ moles $\mathrm{dm}^{-3} \mathrm{~d}^{-1}$, respectively. In the first half of the experiment glycine accounted for 80 molecular percent of the dissolved amino acids. Lysine made up the same proportion in the second experimental period. Glutamic acid, serine and alanine had relative concentrations reaching 20 molecular percent while all other components remained under $10 \%$. Several positive, significant rank correlations were found among the amino acids. Figure 6 shows the compounds with the most frequent significant correlations.

A number of amino acids, particularly valine, leucine and isoleucine, are significantly correlated with plankton groups and individual plankton species such as Nitzschia longissima, Thalassiosira rotula, Prorocentrum micans, Ceratium spec. and the adult copepods (Fig. 7). In contrast to the diatoms, the dinoflagellates taken collectively only have positive significant correlations with threonine. The total concentration of dissolved amino acids and several individual amino acids are significantly positively correlated with the chlorophyll concentration. There are several negative correlations with nitrate and, especially, with ammonia.

\begin{tabular}{|c|c|c|c|c|c|c|c|c|c|}
\hline Phyto-and Zooplankton & & $\bullet$ & $\bullet$ & $\bullet$ & $\bullet$ & - & - & & - \\
\hline Phytoplankton & & - & $\bullet$ & - & $\bullet$ & - & 0 & $\bullet$ & O \\
\hline Datoms & $\bullet$ & & $\bullet$ & $\bullet$ & & - & $\bullet$ & - & - \\
\hline \multicolumn{10}{|l|}{ Nitzschia longissima } \\
\hline \multicolumn{10}{|l|}{ Thalas siosisa rotula } \\
\hline Dinoflagellates & & - & & & & & & & \\
\hline Prorocentrum micans & & - & & $\bullet$ & & 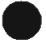 & - & & \\
\hline \multicolumn{10}{|l|}{ Ceratium sp. } \\
\hline Zooplankton & $\bullet$ & & & $\bullet$ & & & & & \\
\hline \multicolumn{10}{|l|}{ Copepods (aduit) } \\
\hline Chlorophyll & $\bullet$ & - & $\bullet$ & 0 & - & 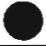 & $\bullet$ & $\bullet$ & - \\
\hline $\mathrm{NO}_{3}^{-}$ & & & & & & & 0 & 0 & 0 \\
\hline \multirow[t]{2}{*}{$\mathrm{NH}_{4}^{+}$} & 0 & & & 0 & 0 & 0 & 0 & 0 & 0 \\
\hline & 亲 & ह & $\frac{O}{T}$ & $\overline{0}$ & $\stackrel{\Xi}{J}$ & $\stackrel{\Perp}{=}$ & जे & के & $\frac{u}{0}$ \\
\hline
\end{tabular}

Fig. 7. Rank-correlations of amino acids with some ecosystem-factors. Open symbols: negative correlations. For statistical probability see legend to Figure 3. TAA: total amino acids

\section{DISCUSSION}

The well-defined plankton succession observed in the tank over a period of $28 \mathrm{~d}$ (Brockmann et al., $1977 \mathrm{a}$ and in preparation) appears to have been responsible for distinct variations in the concentrations of dissolved carbohydrates and, especially, dissolved amino acids.

\section{Neutral Carbohydrates}

The concentration range of dissolved neutral carbohy-

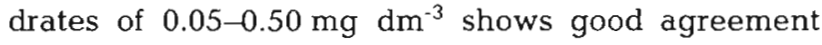


with the results of Walsh and Douglas (1966), Kawahara et al. (1967), Okaichi (1967), Handa (1970) and Burney and Sieburth (1977) from various marine areas.

The individual monosaccharides, with the exception of fucose, all have been previously detected in sea water samples by Wangersky (1952), Lewin (1956), Degens et al. (1964), Handa and Yanagi (1969), Handa (1970) and Josefsson (1970). Nevertheless, fucose, among other carbohydrates, has been found frequently in marine diatoms and their release products (Lewin et al., 1958; Parsons et al., 1961; Coombs and Volcani, 1968; Hecky et al., 1973; Haug and Myklestad, 1976). The ratio hexoses to pentoses in the tank of about 12 corresponds to that found by Hirayama (1974) off the Japanese coast.

Glucose was present in concentrations $(0.2-1.9$ $\mu$ moles $\mathrm{dm}^{-3}$ ) similar to those found by Vaccaro et al. (1968) along a section in the Atlantic Ocean (0.3-0.8 $\mu$ moles $\mathrm{dm}^{-3}$ ), as well as to our values from summer of 1973 near Helgoland (0.2 $\mu$ moles $\mathrm{dm}^{-3}$ ) (Brockmann et al., unpublished). Andrews and Williams (1971), however, detected only $0.002-0.03 \mu$ moles $\mathrm{dm}^{-3}$ of glucose in the English Channel.

Glucose, always accounting for at least $50 \%$ of dissolved monosaccharides in our tank, has often been observed to be the major carbohydrate component, particularly in the euphotic zone and in the phytoplankton (Parsons et al., 1961; Handa, 1969; Handa and Tominaga, 1969; Handa and Yanagi, 1969; Handa, 1970; Myklestad et al., 1972; Hecky et al., 1973; Haug and Myklestad, 1976). Highly positive correlations among monosaccharides implies that they have originated from hydrolysis of heteropolysaccharides. The concentration increase of glucose in the first third of the experimental period is probably related to the occurence of Lauderia borealis. The maximum concentration of dissolved carbohydrates was observed in the stationary phase of Lauderia borealis; this is in agreement with the findings of Myklestad (1977) and our own studies of monocultures of Thalassiosira rotula (Brockmann et al., unpublished).

The maximum rate of increase for glucose of 0.7

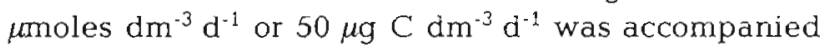
by an increase in particulate carbon $\left(175 \mu \mathrm{g} \mathrm{C} \mathrm{dm}{ }^{-3} \mathrm{~d}^{-1}\right)$ and diatoms ( $40 \mu \mathrm{g} \mathrm{C} \mathrm{dm}{ }^{-3} \mathrm{~d}^{-1}$ between the 5 th and 7 th day). Thus, at this time the dissolved carbohydrates increased at a rate greater than the development of the phytoplankton biomass. The maximum carbohydrate concentration $\left(190 \mu \mathrm{g} \mathrm{C} \mathrm{dm}^{-3}\right)$ was also greater than that of the phytoplankton biomass $\left(67 \mu \mathrm{g} \mathrm{C} \mathrm{dm}^{-3}\right)$ (Brockmann et al., 1977a).

Since carbohydrates, and glucose polymers in particular, are stored within an intracellular pool, it is probable that they seeped out of the diatoms during grazing (Whittle, 1977; Wangersky, 1978). The sig- nificant positive correlations between various plankton groups and individual carbohydrates support this hypothesis. In this context especially glucose has been found in high concentrations in Chaetoceros sp. and Skeletonema costatum, particularly in the water-soluble fraction (Handa, 1969; Handa and Yanagi, 1969).

The desoxyhexoses fucose and rhamnose have been detected as extracellular carbohydrates along with galactose in Chaetoceros cultures (Haug and Myklestad, 1976). Rhamnose and fucose, along with galactose and mannose have been reported as extracellular products in other diatoms (Allan et al., 1972).

The rapid decrease of extracellular carbohydrates results from heterotrophic utilization (Gocke, 1975, 1977; Williams and Yentsch, 1976). We found a maximum rate of decrease of 30 nmoles glucose $\mathrm{dm}^{-3} \mathrm{~h}^{-1}$, which is in the same range as bacterial uptake (Crawford et al,, 1974; Gocke, 1975, 1977; Seki et al., 1975).

\section{Amino Acids}

We found total concentrations in the same range as most of the authors reviewed by Dawson and Pritchard (1978)

Amino acids spectra (Fig. 5) agree with data published by Bohling $(1970,1972)$ with respect to concentrations, parallel development, investigation area and time of year.

The findings of Pocklington (1971), Williams (1975), Whittle (1977), and others, that phytoplankton is a significant source of amino acids dissolved in sea water are confirmed by positive, significant correlations (Fig. 7). The monomeric compounds are most probably released by diffusion (Hellebust, 1974). The amino acids asparaginic acid, glutamic acid, threonine, isoleucine, glycine, serine, alanine, valine and leucine are synthesized de novo within seconds by unicellular algae in the course of primary production (Beardall et al,, 1976). It might be conceivable that some of them are released from intracellular pools in the course of biosynthesis. In this context, significant positive interrelationships between individual amino acids are of particular interest: phenylalanine and tyrosine; threonine, isoleucine, asparaginic acid; and alanine, valine und leucine (Fig. 6).

Zooplankton biomass (Brockmann et al., in preparation) is significantly correlated to total dissolved amino acids indicating another amino acid source from release by zooplankton (cf. Corner and Davies, 1971) or the process of grazing (Wheeler et al., 1974, 1977; Sepers, 1977). Adult copepods appear to be of importance in this respect (Fig. 7).

The decrease in inorganic nitrogen is accompanied by an increase in organic nitrogen compounds (Fig. 4), 
as confirmed by significant, negative correlations, particularly in the case of ammonia and individual amino acids (Fig. 7). Diatoms appear to play a key role here, as reflected by the negative correlations with ammonia and nitrate (Brockmann et al., 1977a), as well as positive correlations with amino acids, which may thus have a stabilizing effect by nutrient conservation (Wangersky, 1977).

It is assumed that uptake of dissolved amino acids by heterotrophic bacteria is considerably more important in the open water than uptake by phytoplankton ( $\mathrm{Hol}-$ libaugh, 1976; Hoppe, 1976). The maximum rate of decrease of lysine amounting to 21 nmoles $\mathrm{dm}^{-3} \mathrm{~h}^{-1}$ corresponds to bacterial uptake rates (Crawford et al., 1974; Seki et al., 1975; Gocke, 1977).

In summary, plastic bags have been shown as a useful experimental tool for the detection of ecological processes. They represent the necessary link between small-scale laboratory experiments and sampling in the open sea. They have enabled the comprehension of interrelationships between plankton organisms and DOM, by excluding hydrodynamic factors. In this way hitherto unknown rapid concentration changes of DOM could be detected during a plankton succession.

Acknowledgements. We wish to express our appreciation to Mrs. U. Rieper, Ch. Freerks, B. Schaab, S. Euteneuer, I. Büns and $\mathrm{G}$. Hahn for their valuable assistance.

\section{LITERATURE CITED}

Allan, G. G., Lewin, J. and Johnson, P. G. (1972). Marine Polymers. IV. Diatom polysaccharides. Botanica mar., 15 , 102-108.

Anderson, G. C. and Zeutschel, R. P. (1970). Release of dissolved organic matter by marine phytoplankton in coastal and offshore areas of the Northeast Pacific Ocean. Limnol. Oceanogr., 15, 402-407.

Andrews, P. and Williams, P. J. LeB. (1971). Heterotrophic utilization of dissolved organic compounds in the sea. III. Measurement of the oxidation rates and concentration of glucose and amino acids in sea water. $J$. mar. biol. Ass. U. K., 51, 111-125.

Antia, N. J., McAllister, C. D., Parsons, T. R., Stephens, K. and Strickland, J. D. H. (1963). Further measurements of primary production using a large volume plastic sphere. Limnol. Oceanogr., 8, 166-183.

Antia, N. J., Berland, B. R., Bonin, D. J. and Maestrini, S. Y. (1975). Comparative evaluation of certain organic and inorganic sources of nitrogen for phototrophic growth of marine microalgae. J. mar. biol. Ass. U. K., 55, 519-539.

Bada, J. L. and Lee, C. (1977). Decomposition and alteration of organic compounds dissolved in seawater. Mar. Chem., 5 $523-534$

Beardall, J., Murkerji, D., Glover, H. E. and Morris, I. (1976) The path of carbon in photosynthesis by marine phytoplankton. J. Phycol., 12, 409-417.
Bhakti, T., Chambers, R. E. and Clamp, J. R. (1970). The gaschromatographic properties of biologically important n-acetyl glucosamine derivatives, monosaccharides, disaccharides, trisaccharides, and pentasaccharides. Biochim. Biophys. Acta, 222, 339-347.

Bohling, H. (1970). Untersuchungen über freie gelöste Aminosäuren in Meerwasser. Mar. Biol., 6, 213-225.

Bohling, H. (1972). Gelöste Aminosäuren in Oberflächenwasser der Nordsee bei Helgoland: Konzentrationsveränderungen im Sommer 1970. Mar. Biol., 16, 281-289.

Brockmann, U. H., Eberlein, K., Junge, H. D., Maier-Reimer, E., Siebers, D. and Trageser, H. (1974a). Entwicklung natürlicher Planktonpopulationen in einem outdoor-Tank mit nährstoffarmem Meerwasser. II Konzentrationsverändenungen von gelösten neutralen Kohlenhydraten und freien gelösten Aminosäuren. Ber. Sonderforsch. Meeresforsch., Hbg., 6, 166-180.

Brockmann, U. H., Eberlein, K., Junge, H. D., Trageser, H., und Trahms, K. J. (1974b). Einfache Folientanks zur Planktonuntersuchung in situ. Mar. Biol., 24, 163-166.

Brockmann, U. H., Eberlein, K., Hosumbek, P., Trageser, H. Maier-Reimer, E., Schöne, H. K. and Junge, D. H. (1977a). The development of a natural plankton population in an outdoor tank with nutrient-poor sea water. I. Phytoplankton succession. Mar. Biol., 43, 1-17.

Brockmann, U. H., Eberlein, K., Hentzschel, G., Schöne, H. Siebers, D., Wandschneider, K. and Weber, A. (1977b). Parallel plastic tank experiments with cultures of marine diatoms. Helgoländer wiss. Meeresunters., 30, 201-216.

Brockmann, U. H., Trahms, J., Eberlein, K., Junge, H. D., Maier-Reimer, E. and Trageser, H. (in prep.). The development of a natural plankton population in an outdoor tank with nutrient-poor sea water. III. Succession and development of zooplankton.

Burney, C. M. and Sieburth, J. McN. (1977). Dissolved carbohydrates in sea water. II. A spectrophotometric procedure for total carbohydrate analysis and polysaccharide estimation. Mar. Chem., 5, 15-28.

Butler, E. I., Corner, E. D. S. and Marshall, S. M. (1970). On the nutrition and metabolism of zooplankton. VII. Seasonal survey of nitrogen and phosphorus excretion by Calanus in the Clyde Sea Area. J. mar. biol. Ass. U. K., 50 , $525-560$.

Clamp, J. R., Dawson, G. and Hough, L. (1967). The simultaneous estimation of 6-deoxy-l-galactose (l-fucose), dmannose, d-galactose, 2-acetamido-2-deoxy-d-glucose (nacetyl-d-glucosamin) and n-acetylneuraminic acid (sialic acid) in glycopeptides and glycoproteins. Biochim. biophys. Acta, 148, 342-349.

Conover, R. J. (1978). Transformation of organic matter. In $O$. Kinne (Ed.), Marine Ecology, Vol. IV, Dymamics. Wiley, Chichester. pp. 221-499.

Corner, E. D. S. and Davies, A. G. (1971). Plankton as a factor in the nitrogen and phosphorus cycles in the sea. Adv. Biol., 9, 101-204.

Coombs, J. and Volcani, B. E. (1968). Studies on the biochemistry and fine structure of silicia-shell formation in diatoms. Chemical changes in the wall of Navicula pelliculosa during its formation. Planta, 82, 280-292.

Cowey, C. B. and Corner, E. D. S. (1963). Amino acids and some other nitrogenous compounds in Calanus finmarchicus. J. mar. biol. Ass. U. K., 43, 485-493.

Crawford, C. C., Hobbie, J. E. and Webb, K. L. (1974). The utilization of dissolved free amino acids by estuarine microorganisms. Ecology, 55, 551-563.

Degens, E. T. (1970). Molecular nature of nitrogenous compounds in sea water and recent marine sediments. In D. W. 
Hood (Ed.), Organic Matter in Natural Waters. Inst. Mar. Sci., Alaska. pp. 77-106.

Degens, E. T., Reuter, J. H. and Shaw, K. N. F. (1964) Biochemical compounds in offshore California sediments and sea waters. Geochim. cosmochim. Acta, 28, 45-66.

Duce, R. A. and Duursma, E. K. (1977). Inputs of organic matter to the ocean. Mar. Chem., 5, 319-339.

Fogg, G. E. (1975). Primary Productivity. In J. Riley and G. Skirrow (Eds), Chemical Oceanography, Vol. II. (2nd ed.) Academic Press, New York. pp. 385-453.

Fogg, G. E. (1977). Excretion of organic matter by phytoplankton. Limnol. Oceanogr., 22, 576-577.

Gocke, K. (1970). Untersuchungen über Abgabe und Aufnahme von Aminosäuren und Polypeptiden durch Planktonorganismen. Arch. Hydrobiol., 67, 285-367.

Gocke, K. (1975). Untersuchungen über die Aufnahme von gelöster Glukose unter natuirlichen Verhältnissen durch größenfraktioniertes Nano- und Ultrananoplankton Kieler Meeresforsch., 31, 87-94.

Gocke, K. (1977). Comparison of methods for determining the turnover times of dissolved organic compounds. Mar. Biol., 42, 131-141.

Handa, N. (1969). Carbohydrate metabolism in the marine diatom Skeletonema costatum, Mar. Biol., 4, 208-214.

Handa, N. (1970). Dissolved and particulate carbohydrates. In D. W. Hood (Ed.), Organic Matter in Natural Waters. Inst. Mar. Sci., Alaska. pp. 129-152.

Handa, N. and Tominaga, H. (1969). A detailed analysis of carbohydrates in marine particulate matter. Mar. Biol, 2 , 228-235.

Handa, N. and Yanagi, K. (1969). Studies on water-extractable carbohydrates of the particulate matter from the northwest Pacific Ocean. Mar. Biol., 4, 197-207.

Haug, A. and Myklestad, S. (1976). Polysaccharides of marine diatoms with special reference to Chaetoceros species. Mar. Biol., 34, 217-222.

Hecky, R. E., Mopper, K., Kilham, P. and Degens, E. T. (1973). The amino acid and sugar composition of diatom cellwalls. Mar. Biol., 19, 323-331.

Hellebust, J. A. (1965). Excretion of some organic compounds by marine phytoplankton. Limnol. Oceanogr., 10, 192-206.

Hellebust, J. A. (1974). Extracellular Products. In W. D. P. Stewart (Ed.), Algal Physiology and Biochemistry. Blackwell, Oxford. pp. 838-863. (Bot. Monogr. 10.)

Hirayama, H. (1974). Fluorimetric determination of carbohydrates in sea water. Anal. chim. Acta, 70, 141-148.

Hollibaugh, J. T. (1976). The biological degradation of arginine and glutamic acid in seawater in relation to the growth of phytoplankton. Mar. Biol., 36, 306-312.

Hoppe, H -G. (1976). Determination and properties of actively metabolizing heterotrophic bacteria in the sea, investigated by means of micro-autoradiography. Mar. Biol., 36, 291-302.

Jeffries, H. P. (1969). Seasonal composition of temperate plankton communities: free amino acids. Limnol. Oceanogr, 14, 41-52.

Johannes, R. E. and Webb, K. L. (1965). Release of dissolved amino acids by marine zooplankton. Science, N. Y., 150, $76-77$.

Johannes, R. E. and Webb, K. L. (1970). Release of dissolved organic compounds by marine and freshwater invertebrates. Organic matter in natural water. Institute of Marine Science, Occ. Publs, 1, 257-273.

Josefsson, B. O (1970). Determination of soluble carbohydrates in sea water by partition chromatography after desalting by ion exchange membrane electrodialysis. Anal. chim. Acta, 52,65-73.

Kawahara, H., Maita, Y. and Ishii, J. (1967). Studies on the organic matter in sea water. I. The distribution of carbohydrates in water of southern Hokkaido. Bull. Jap. Soc. scient. Fish., 33, 825-833.

Lewin, R. A. (1956). Extracellular polysaccharides of green algae. Can. J. Microbiol., 2, 665-672.

Lewin, J. C., Lewin, R. A. and Philpott, D. E. (1958). Observation on Phaeodactylum tricornutum. J. gen. Microbiol., 18, $418-426$.

Liu, M. S. and Hellebust, J. A. (1974). Uptake of amino acids by the marine centric diatom Cyclotella cryptica. Can. J. Microbiol., 20, 1109-1118.

McAllister, C. D., Parsons, T. R., Stephens, K. and Strickland, J. D. H. (1961). Measurements of primary production in coastal sea water using a large volume plastic sphere. Limnol. Oceanogr., 6, 237-258.

Morris, A. W. and Foster, P. (1971). The seasonal variation of dissolved organic carbon in the inshore waters of the Menai Strait in relation to primary production. Limnol. Oceanogr., 16, 987-989.

Myklestad, S. (1974). Production of carbohydrates by marine planktonic diatoms. I. Comparison of nine different species in culture. J. exp. mar. Biol. Ecol., 15, 261-274.

Myklestad, S. (1977). Production of carbohydrates by marine planktonic diatoms. II. Influence of the N/P ratio in the growth medium on the assimilation ratio, growth rate, and production of cellular and extracellular carbohydrates by Chaetoceros affinis var. willei (Gran) Hustedt and Skeletonema costatum (Grev.) Cleve. J. exp. mar. Biol. Ecol., 29, 161-179.

Myklestad, S., Haug, A. and Larsen, B. (1972). Production of carbohydrates by the marine diatom Chaetoceros affinis var. willei (Gran) Hustedt. II. Preliminary investigation of the extracellular polysaccharide. J. exp. mar. Biol. Ecol., 9, $137-144$.

Nalewajko, C. (1966). Photosynthesis and excretion in various planktonic algae. Limnol. Oceanogr., 11, 1-10.

Niedermeier, W. (1971). Gas chromatography of neutral and amino sugars in glycoproteins. Anal. Biochem., 40, $465-475$.

North, B. B. and Stephens, G. C. (1969). Dissolved amino acids and Platymonas nutrition. Proc. Int. Seaweed Symp., 6, $263-273$.

Okaichi, T. (1967). Red tides found in and around the Soto Inland Sea. Kagawa daigaku nogakubu gakujutsu Hokuku, 18, 181-185.

Palmork, K. H. (1969). Amino acids in sea water by gas chromatography. Int. Counc. Explor. Sea, Hydrography Committee, C $17 \mathrm{CM}$.

Parsons, T. R., Stephens, K. and Strickland, J. H. D. (1961). On the chemical composition of eleven species of marine phytoplankters. J. Fish. Res. Bd Can., 18, 1001-1016.

Pocklington, R. (1971). Free amino acids dissolved in North Atlantic Ocean waters. Nature, Lond., 230, 374-375.

Seki, H., Yamaguchi, Y. and Ichimura, S. (1975). Turnover rate of dissolved organic materials in a costal region of Japan at summer stagnation period of 1974. Arch. Hydrobiol., 75, 297-305.

Sepers, A. B. J. (1977). The utilization of dissolved organic compounds in aquatic environments. Hydrobiologia, 52, $39-54$.

Sharp, J. H. (1977). Excretion of organic matter by marine phytoplankton: Do healthy cells do it? Limnol. Oceanogr., 22, 381-399. 
Siebers, D., Lucu, C., Sperling, K.-R. and Eberlein, K. (1972). Kinetics of osmoregulation in the crab Carcinus maenas. Mar. Biol., 17, 291-303.

Siegal, A. and Degens, E. T. (1966). Concentration of dissolved amino acids from saline waters by ligand-exchange chromatography. Science, N. Y., 151, 1098-1101.

Smith, D. F. and Wiebe, W. J. (1976). Constant release of photosynthate from marine phytoplankton. Appl. Envir. Microbiol., 32, 75-79.

Smith, W. O., Jr., Barber, R. T. and Huntsman, S. A. (1977). Primary production off the coast of northwest Africa: excretion of dissolved organic matter and its heterotrophic uptake. Deep Sea Res., 24, 35-47.

Storch, T. A. and Saunders, G. W. (1978). Phytoplankton extracellular release and its relation to the seasonal cycle of dissolved organic carbon in an eutrophic lake. Limnol. Oceanogr., 23, 112-119.

Thomas, J. P. (1971). Release of dissolved organic matter from natural populations of marine phytoplankton. Mar. Biol., $11,311-323$

Vaccaro, R. F., Hicks, S. E., Jannasch, H. W. and Carey, F. G. (1968). The occurrence and role of glucose in seawater. Limnol. Oceanogr., 13, 356-360.

Vance, D. E. and Sweeley, C. C. (1967). Quantitative determination of the neutral glycosyl ceramides in human blood. J. Lipid Res., 8, 621-630.

Walsh, G. E. and Douglas, J. (1966). Vertical distribution of dissolved carbohydrates in the Sargasso Sea off Bermuda. Limnol. Oceanogr., 11, 406-408.

Wangersky, P. J. (1952). Isolation of ascorbis acid and rhamnosides from sea water. Science, N. Y., 115, 685
Wangersky, P. J. (1972). The cycle of organic carbon in sea water. Chimia, 26, 559-564.

Wangersky, P. J. (1977). The role of particulate matter in the productivity of surface waters. Helgoländer wiss. Meeresunters., 30, 546-564.

Wangersky, P. J. (1978). Production of dissolved organic matter. In O. Kinne (Ed.), Marine Ecology, Vol. IV. Wiley, Chichester. pp. 115-220.

Webb, K. L. and Johannes, R. E. (1967). Studies of the release of dissolved free amino acids by marine zooplankton. Limnol. Oceanogr., 12, 376-382.

Webb, K. L. and Johannes, R. E. (1969). Do marine crustaceans release dissolved amino acids? Comp. Biochem. Physiol., 29, 875-878.

Wheeler, P. A., North, B. B. and Stephens, G. C. (1974). Amino acid uptake by marine phytoplankters. Limnol. Oceanogr., 19, 249-259.

Wheeler, P. A., North, B. B., Littler, M. and Stephens, G. (1977). Uptake of glycine by natural phytoplankton communities. Limnol. Oceanogr., 22, 900-910.

Whittle, K. J. (1977). Marine organisms and their contribution to organic matter in the ocean. Mar. Chem., 5, 381-411.

Williams, P. J. LeB. (1975). Biological and chemical aspects of dissolved organic material in sea water. In J. P. Riley and G. Skirrow (Eds), Chemical Oceanography, Vol. II (2nd ed.) Academic Press, London. pp. 301-363.

Williams, P. J. LeB. and Yentsch, C. S. (1976). An examination of photosynthetic production, excretion of photosynthetic products, and heterotrophic utilization of dissolved organic compounds with reference to results from a coastal subtropical sea. Mar. Biol., 35, 31-40. 